\title{
Congo Grey Parrot Psittacus erithacus densities in oil palm plantation, agroforestry mosaic and protected forest in Southwest Cameroon*
}

\author{
SASCHA DUEKER, DENIS KUPSCH, SERGE KADIRI BOBO, \\ ECKHARD W. HEYMANN and MATTHIAS WALTERT
}

\section{Summary}

The Congo Grey Parrot Psittacus erithacus has experienced a severe population breakdown in recent decades. The rainforests of the Korup region in Southwest Cameroon may harbour a large population of this species, but density and population estimates from this area remain controversial. Before the 2016 breeding season, we surveyed Grey Parrots along transects (621.1 km survey effort) in three adjacent landscape types: primary forest in Korup National Park (KNP), smallholder agroforestry matrix (AFM), and industrial oil palm plantation (OPP). We also collected information on the trees used for nesting, feeding and roosting. Using Distance analysis, we estimated relatively low densities of stationary flocks, ranging from 0.30 ind. $/ \mathrm{km}^{2}$ in KNP, over 0.82 ind. $/ \mathrm{km}^{2}$ in OPP to 2.70 ind. $/ \mathrm{km}^{2}$ in the AFM. Parrots were observed feeding or roosting in 17 tree species, of which 15 were located in AFM alone. Feeding was most often observed on cultivated Elaeis guineensis and Dacryodes edulis, but never in maize. The detected parrot densities probably reflect declines within the period 2008-2016, suggesting that the species' recent IUCN uplisting to 'Endangered' and transfer to CITES Appendix I was indeed justified. Our results also suggest that traditional smallholder agroforestry may play a role in habitat conservation strategies, since these forms of cultivation may maintain important breeding and feeding opportunities for Congo Grey Parrots.

\section{Introduction}

Parrots of the genus Psittacus are found mainly in moist forests but also mangroves and wooded savanna across tropical Africa (Naurois 1981, BirdLife International 2017a,b). Phenotypic differentiation suggests that the genus comprises two species: the Congo Grey Parrot Psittacus erithacus and the Timneh Grey Parrot Psittacus timneh (Collar 2013). Distribution ranges are estimated at 4,490,00o $\mathrm{km}^{2}$ for Psittacus erithacus and at $541,000 \mathrm{~km}^{2}$ for Psittacus timneh although recent assessments are lacking (BirdLife International 2017a,b). Grey Parrots were still 'common to abundant' in parts of their range in the early 1980s (Green et al. 2007, Tamungang and Cheke 2012; see also Martin et al. 2014a). Recently, an estimated population decline of 50-79\% within three generations has been suggested (47 years; BirdLife International 2017a). In Ghana, it has been estimated that $90-99 \%$ of the population has been lost since 1992 accompanied by regional extinctions (Annorbah et al. 2016). Consequently, Congo Grey Parrots are categorised as 'Endangered' by IUCN (BirdLife International 2017a) and listed in CITES Appendix I (CITES 2016).

${ }^{*}$ The online version of this article has been updated since original publication. A notice detailing the changes has also been published at https://doi.org/10.1017/S0959270919000297. 
Due to their worldwide popularity as pets, Grey Parrots are among the most frequently traded parrots. (Chupezi et al. 2006, Martin et al. 2014a, Martin 2018a). Since 1975, net exports of more than 1.22 million wild Grey Parrots have been reported in international trade by CITES parties (Martin 2018b). Until 2016, national export quotas were 5,000 and 3,000 for the Democratic Republic of Congo and Cameroon, respectively (CITES 2016, Martin 2018b). Given high mortality $(40-60 \%)$ during trapping and transport (Fotso 1998a,b, McGowan 2001) as well as additional illegal export, the real yearly harvest was likely considerably higher than the stated quotas (BirdLife International 2017a). In Cameroon alone, some 100,000 birds per year were probably being captured during the late 1990s and early 2000s (BirdLife International 2017a).

Furthermore, Grey Parrots may also be impacted by forest loss and degradation, such as reduced availability of large nesting trees as a consequence of logging (Martin et al. 2014a). In Africa, highvalue timber species such as Terminalia superba are commonly used as breeding trees by Grey Parrots (Annorbah et al. 2016). There is some evidence on the occasional use of Grey Parrots as bushmeat, for ceremonies or medicinal purposes (Fotso 1998a, McGowan 2001, Clemmons 2003, Fa et al. 2006, Eniang et al. 2008, authors' unpubl. data), though the impacts on wild populations remain unclear.

The rainforests of the Korup region in Southwest Cameroon are still largely unfragmented (Kupsch et al. 2019) and should therefore be an important stronghold of the species. Based on survey data from 2008 to 2010 , Tamungang et al. (2013) provided a population estimate for Southwest Cameroon as well as a more detailed assessment on habitat preferences in three landscape types (Tamungang et al. 2016), however, Martin et al. (2014b) criticised both their field and analysis methodology as deficient and prone to biases.

In order to update information from the same three landscape types, we collected data during the pre-breeding season 2016, c.7 years after the surveys of Tamungang et al. (2016). We also report incidental observations on the trees used for feeding, breeding and roosting in order to inform assessments of habitat quality for the species. We assumed that habitat quality and parrot abundance would vary with the availability of these resources. Based on Tamungang et al. (2016), we expected to estimate higher parrot densities in a traditional smallholder agroforestry landscape compared to undisturbed primary forests or industrial oil palm plantations.

\section{Materials and methods}

\section{Study area}

The study was conducted in and around Korup National Park (KNP) in Southwest Cameroon (Figure I) congruent with the study area of the surveys in 2008-2010 by Tamungang et al. (2016). Surveys were done between 23 March and 4 June 2016 during the pre-breeding season (pers. obs.). With c.26,00o km², the forest block of SE Nigeria/SW Cameroon is the largest remaining, relatively intact continuous rainforest in the "Guinean Forests of West Africa" biodiversity hotspot, which holds at least 416 mammal and 917 bird species (Mittermeier et al. 2004). The largest urban area close to the park is the capital of Ndian division, Mundemba, with 5,000-6,000 inhabitants.

We collected data in three different adjacent landscape types: (i) the primary forests of the southern sector of KNP, (ii) the agroforestry matrix landscape shaped by traditional smallholder activities (AFM) in the eastern surroundings of the park, and (iii) in an industrial oil palm plantation (OPP) at the southern border of the park.

\section{Korup National Park}

KNP is approx. $1,260 \mathrm{~km}^{2}$ in size and was created in 1986 with its western border adjacent to Nigeria (Figure 1). It is characterised as primary forest, classified as Oubangia alata (Scytopetalaceae) coastal forest with an annual rainfall of more than 4,000 $\mathrm{mm}$ (Thomas 1996). KNP harbours 419 bird species (Bobo et al. 2005). The fieldwork was based at Chimpanzee Camp $\left(5.069^{\circ} \mathrm{N}, 8.860^{\circ} \mathrm{E}\right)$, which is located $10 \mathrm{~km}$ from the national park entrance, Mana footbridge. The closest settlements were 


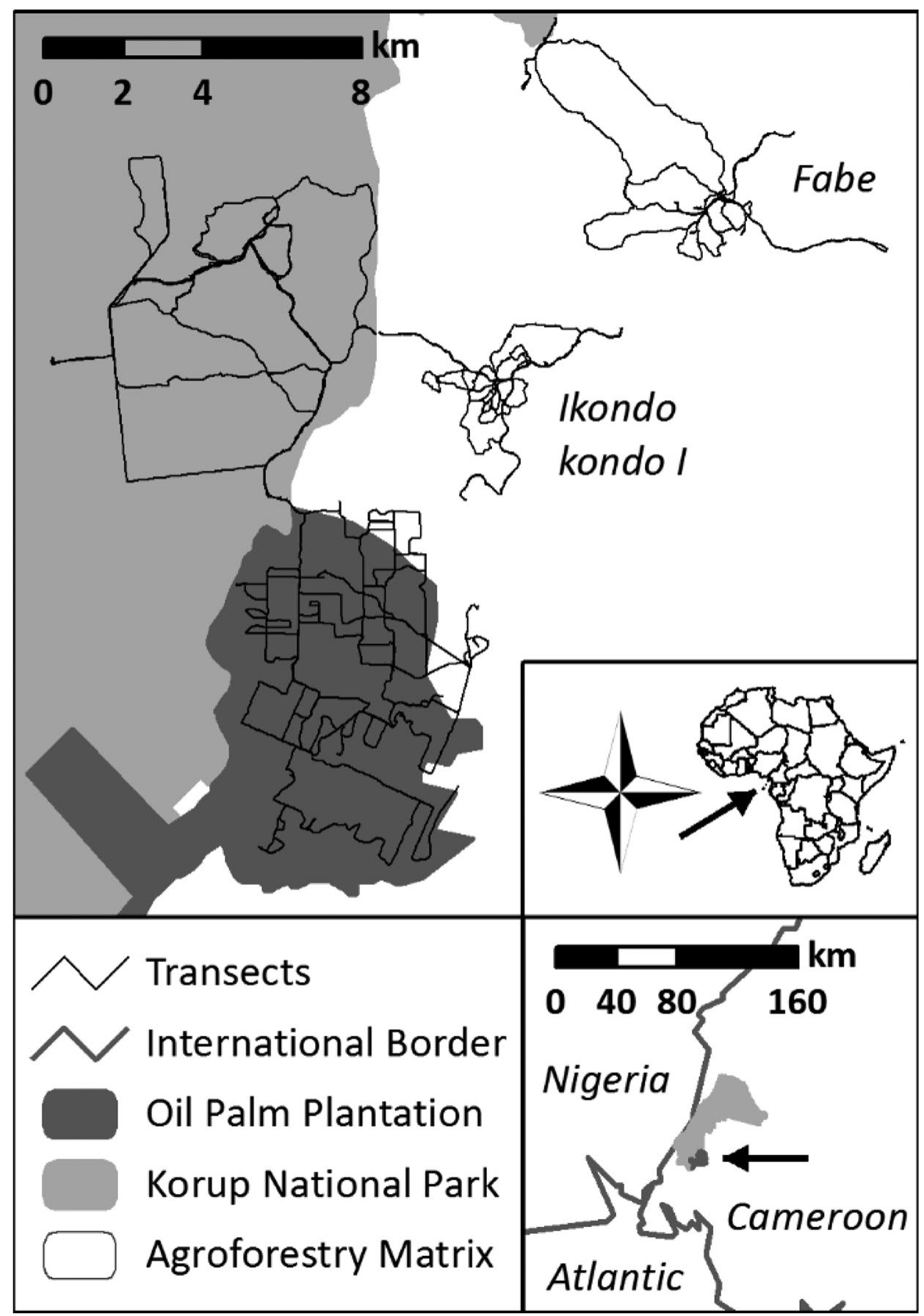

Figure 1. Study area in and around Korup National Park in Southwest Cameroon. 
the villages Ikondo kondo 1 and Erat, and the workers camps of the PAMOL oil palm plantation. The area is intersected by small to medium-sized creeks and rivers during the wet season.

\section{Agroforestry matrices}

Data were collected in an area containing two rural villages close to the park, both of them with around 150 inhabitants. These were Ikondo kondo $I$ and Fabe, which are located c.7.5 km and $15 \mathrm{~km}$ north-east of Mundemba, respectively (Figure 1). These villages are mainly inhabited by traditional smallholder families, who plant a mixture of subsistence and cash crops in and around their villages within a landscape dominated by remaining primary and secondary forests (Kupsch et al. 2019). Fire is often used to clear small areas inside forest, often in the shade of old trees, e.g. for cacao Theobroma cacao. Around these villages, forest patches are relatively undisturbed and used for hunting. Therefore, and because of minimal application of pesticides, the current smallholders' impact on the forest environment is minor.

\section{Oil palm plantations}

The OPP in the west of Mundemba is an estate of PAMOL Plantations Plc. The plantation area covers $58.04 \mathrm{~km}^{2}$ and is systematically partitioned in monocultural fields of Elaeis guineensis. It borders KNP and holds some remnants of forest along two large streams and steep slopes.

\section{Data collection}

Following the procedures employed by Legault et al. (2013) and Marsden et al. (2015), we collected data from transects, and report both encounter rates and densities for stationary parrot flocks. These walks follow paths of least resistance through dense habitat (Walsh and White 1999). We used a GPS device to record the paths walked and measured perpendicular distances from the transect line to Grey Parrot flocks with a rangefinder. To increase accuracy and discernment, all transects were walked at least once by two observers (Legault et al. 2013). Transects were walked directly after dawn between o6hoo and 10hoo, and before dusk between 16hoo and 19hoo, when parrot activity was highest. We did not survey under strong wind or rain, as these might strongly affect detectability (Lee and Marsden 2012).

\section{Data analysis}

To estimate density, we modelled detection probability using the Conventional Distance Sampling engine (Buckland et al. 2001) of Distance 6.0, release 2 (Thomas et al. 2010). Since fast-flying parrots are violating assumptions of Distance methodology, potentially inflating density estimates, we ignored overflies in calculations of density (Buckland et al. 2001). Most studies follow this convention (including Tamungang et al. 2013, 2016). Different truncation distances were used to model data from each of the landscape types, as well as for data from all three landscape types combined. Different key functions (uniform, half-normal and hazard-rate) in combinations of series adjustments (cosine, simple polynomial and hermite polynomial) were fitted to the data. Finally, visual examination, Chi-square goodness of fit tests, and eventually the Akaike's Information Criterion (AIC) were used to evaluate model fit (Buckland et al. 2001, Thomas et al. 2010). AIC values from stratified data were compared to those from a global detection function, to assess the reliability of a global detection probability estimate. Since the sum of AIC values from stratified data was higher than the $\mathrm{AIC}$ value from a global detection function $\left(\mathrm{AIC}_{\text {global }}=170.17, \sum \mathrm{AIC}_{\text {stratified }}=171.80\right)$, densities were estimated based on a global detection probability function for data truncated to a strip width of $w=127 \mathrm{~m}$. The half-normal/cosine detection function was found to be most reliable to assess detection probability $P$. The chosen function had eight intervals and detection probability was estimated at $P=0.55$ (12.56\% CI; Figure $\mathrm{S}_{1 \mathrm{a}}$ in the online supplementary material). For density 
calculations in each stratum, we used a global estimate of expected flock size $E(S)$ based on the size-biased regression method, regressing $\ln$ (flock size) against estimated detection probability $g(x)$. We used a global estimate of flock size since records of stationary flocks in Korup National Park were only $n=5$. Size-biased regression suggested that smaller flocks were underrepresented at larger distances from transects to some extent: expected flock size was estimated at 2.40 individuals per flock (95\% CI: 1.88-3.08) whereas average flock size was estimated at 3.32 individuals per flock (95\% CI: 2.17-5.07). Density estimates in the three different landscape types were compared using a Z-test with a two-tailed $P$-value, and using the Delta method.

\section{Field observations on feeding, breeding and roosting sites}

When encountering a stationary flock of Grey Parrots during surveys, observations on feeding, breeding and roosting trees were made following Reuleaux et al. (2014a, b). In addition, we noted the number of individuals, which aggregated for resting or sleeping. We recorded the location of feeding, breeding and roosting with a GPS. We also took pictures from the trees utilised for later analysis. Leaves, seeds and fruits falling to the ground were collected and identified later with the help of a local botanist. Moreover, the number of individual parrots was noted, activity was described as breeding, roosting, feeding or sitting, and the height of the respective tree measured using the range finder.

As repeated use of successful nests is very common among many cavity-nesters (Sedgwick 1997), particularly parrots (Gnam 1991, Pinho and Nogueira 2003), we asked local farmers to show us known breeding sites, i.e. areas where they observed either eggs, chicks or adult birds in and around a cavity for an extended period, and showing characteristic behaviour, such as inspections of the cavity or sentinel behaviour (see the Marsden et al. 2001 classification for 'active' nests).

\section{Results}

\section{Parrot encounter metrics and density estimation}

In total we walked 68 transects and $621.1 \mathrm{~km}$ across the three different landscapes (Table 1 ), of which most $(k=28, L=286.8 \mathrm{~km})$ were allocated to KNP. However, here we also recorded the lowest numbers of flocks of Grey Parrots (20 overflying and five stationary flocks). After truncation to $w=127 \mathrm{~m}$, encounter rates of stationary flocks were lower in $\mathrm{KNP}$ (flocks $n / L=0.02 \mathrm{ind} . / \mathrm{km}$ ) and OPP $(n / L=0.05$ ind. $/ \mathrm{km})$ than in AFM $(n / L=0.16$ ind. $/ \mathrm{km}$; Table 2$)$. Whereas both overflying and stationary flocks in AFM and OPP consisted of less than three individuals on average, they were much larger in $\mathrm{KNP}\left(E(s)_{\text {overfly }}=4.2 \mathrm{O} ; E(s)_{\text {stationary }}=9.4 \mathrm{O}\right.$ ) (Table I). Using the expected flock size estimate from data pooled across landscapes (see methods), density estimates ranged

Table 1. Total transect length $L[\mathrm{~km}]$, number of transects $k$ and flocks $n$ observed, as well as numbers of individuals Ind, and mean flock sizes $E(s)$ including confidence interval (95\% C.I.) of Congo Grey Parrots from surveys in three different landscapes (KNP - Korup National Park, AFM - agroforestry matrix, OPP - oil palm plantation), as well as totals, in the Korup region, Cameroon, in 2016. Mean flock sizes were calculated for data truncated to $127 \mathrm{~m}$.

\begin{tabular}{|c|c|c|c|c|c|c|}
\hline & $L$ & $k$ & Adjustments & $n$ & Ind. & $E(s)(95 \%$ C.I. $)$ \\
\hline \multirow[t]{2}{*}{ KNP } & 286.8 & 26 & all flocks & 25 & 105 & $4.20(2.42-7.30)$ \\
\hline & & & only stationary & 5 & 47 & $9.40(2.15-41.13)$ \\
\hline \multirow[t]{2}{*}{ AFM } & 209.2 & 31 & all flocks & 188 & 532 & $2.81(2.26-3.49)$ \\
\hline & & & only stationary & 42 & 116 & $2.64(1.97-3.53)$ \\
\hline \multirow[t]{2}{*}{ OPP } & 125.1 & 11 & all flocks & 57 & 147 & $2.61(2.12-3.22)$ \\
\hline & & & only stationary & 9 & 18 & $2.00(1.26-3.19)$ \\
\hline \multirow[t]{2}{*}{ Totals } & 621.1 & 68 & all flocks & 270 & 784 & $2.90(2.45-3.44)$ \\
\hline & & & only stationary & 56 & 181 & $3.32(2.17-5.07)$ \\
\hline
\end{tabular}


Table 2. Survey effort $L$, number of flock encounters $n$, encounter rate $n / L$, estimated density D with $95 \%$ confidence interval C.I. for the Congo Grey Parrot Psittacus erithacus in three different landscape types (KNP Korup National park, AFM - agroforestry matrix, OPP - oil palm plantation) in SW Cameroon. Numbers result from using data from stationary flocks (only perched flocks included, see Legault et al. (2013) and Marsden et al. (2015)). $D$ and $N$ estimated using the model half-normal (cosine) from a distance data subset truncated to $w=127 \mathrm{~m}$ and estimated detection probability of $P=0.55$. Densities were calculated using a global estimate of expected flock size $E(S)=2.40$ (95\% C.I.: 1.88-3.08).

\begin{tabular}{llll}
\hline & KNP & AFM & OPP \\
\hline$L$ & $286.8 \mathrm{~km}$ & $209.2 \mathrm{~km}$ & $125.1 \mathrm{~km}$ \\
$n$ untruncated & 5 & 42 & 9 \\
$n$ truncated & 5 & 33 & 6 \\
$n / L(95 \%$ C.I.) untruncated & $0.02(0.01-0.04)$ & $0.20(0.14-0.29)$ & $0.07(0.02-0.27)$ \\
$n / L(95 \%$ C.I. $)$ truncated & $0.02(0.01-0.04)$ & $0.16(0.10-0.24)$ & $0.05(0.02-0.15)$ \\
$D(95 \%$ C.I. $)$ & $0.30(0.13-0.69)$ & $2.70(1.57-4.63)$ & $0.82(0.26-2.62)$ \\
\hline
\end{tabular}

from 0.30 ind. $/ \mathrm{km}^{2}$ in KNP, over 0.82 ind. $/ \mathrm{km}^{2}$ in OPP to 2.70 ind. $/ \mathrm{km}^{2}$ in the AFM. Consequently, estimated density for the AFM was nine times higher than that for KNP (albeit non-significantly; $\Delta Z=0.15, P=0.88)$ and three times higher than that for the OPP $(\Delta Z=-2.53, P=0.01)$, respectively. Estimated parrot densities for the OPP did not differ significantly from that for KNP $(\Delta Z=-0.71, P=0.48)$.

\section{Tree species used}

During transect surveys, we recorded the utilisation of 16 tree species in 48 occasions, in which we observed feeding, roosting or nesting (Table 3). There were significant differences in tree use in regard to the three landscape types. Whereas in KNP and in OPP parrots were only seen in one tree species each, Lecomtedoxa klaineana (Sapotaceae) and Elaeis guineensis (Arecaceae), respectively, in the AFM the parrots were seen in a variety of different tree species.

Table 3. Tree species and their numbers used by Psittacus erithacus in incidental flock observations $\left(n_{\text {total }}=48\right)$ in Korup National Park (KNP), the oil palm plantation (OPP) and the agroforestry matrix (AFM).

\begin{tabular}{llll}
\hline Tree species & Family & \multicolumn{2}{l}{ No. of used trees per landscape type } \\
\cline { 3 - 3 } & & KNP & AFM \\
\hline Lecomtedoxa klaineana & Sapotaceae & IO \\
Elaeis guineensis & Arecaceae & & \\
Terminalia superba & Combretaceae & 6 \\
Dacryodes edulis & Burseraceae & 5 \\
Desbordesia glaucescens & Irvingiaceae & 2 \\
Distemonanthus benthamianus & Leguminosae & 2 \\
Piptadeniastrum africanum & Leguminosae & 2 \\
dead tree & - & 2 \\
Angylocalyx oligophyllus & Leguminosae & 1 \\
Baillonella toxisperma & Sapotaceae & 1 \\
Ceiba pentandra & Malvaceae & 1 \\
Leptaulus daphnoides & Cardiopteridaceae & 1 \\
Lophira alata & Ochnaceae & 1 \\
Morinda lucida & Rubiaceae & 1 \\
spp. & Burseaceae & 1 \\
spp. & Euphorbiaceae & 1 \\
spp. & Icacinaceae & 1 \\
\hline
\end{tabular}


In KNP, Grey Parrots were sighted 10 times perching in L. klaineana. We did not detect signs of feeding, breeding or roosting at this tree species. In the OPP, we had Io parrot encounters in E. guineensis perching, but also feeding on palm nuts. In the AFM, a frequently used tree (six observations) was Terminalia superba (Combretaceae). In one of these, on 2 June 2016, Grey Parrots were inspecting a tree hollow. The second most used tree species, with five observations, was the bush plum Dacryodes edulis (Burseraceae). Parrots fed on its fruits on three occasions. Two observations each were from Desbordesia glaucescens (Irvingiaceae), Distemonanthus benthamianus and Piptadeniastrum africanum (both Leguminosae). On these three trees, parrots were only sighted perching. The family Leguminosae served five times as a host for the parrots in the AFM. Parrots were also found on undetermined dead trees where they showed social and sentinel behaviour, benefiting from open vegetation structures. Generally, parrots were always observed in canopy trees, with Elaeis guineensis and Dacryodes edulis being the lowest. While the latter only reach a height of c.20 m, other forest trees can reach up to $50-60 \mathrm{~m}$. Parrots were never seen on or close to the ground.

\section{Discussion}

\section{Spatial and temporal variation in parrot density estimates}

Our survey results indicate that daytime population densities of Grey Parrots in the Korup region (i) are much lower now than suggested by earlier surveys, (ii) and strongly vary between the three different landscapes. We also found (iii) that human modified landscapes potentially provide a high resource density, even compared to the primary forests of Korup National Park.

Compared to available density estimates for the period 2008-2010 (Tamungang et al. 2016), our estimates from the same study area and season in 2016 were much lower, comprising only $2.7 \%, 7.5 \%$ and $5.5 \%$ of these earlier estimates for KNP (density $D_{2009}=11$ ind. $/ \mathrm{km}^{2}, D_{2016}=0.3$ ind. $\left./ \mathrm{km}^{2}\right), \operatorname{AFM}\left(D_{2009}=36\right.$ ind. $/ \mathrm{km}^{2}, D_{2016}=2.7$ ind. $\left./ \mathrm{km}^{2}\right)$ and OPP $\left(D_{2009}=15 \mathrm{ind} . / \mathrm{km}^{2}, D_{2016}=\right.$ 0.82 ind. $\left./ \mathrm{km}^{2}\right)$, respectively. However, Distance sampling methods are sensitive to biases and, therefore, highly depend on accurate data collection and analysis as well as detailed information on the methods used and assumptions made in order to increase comparability. For the very same reasons absolute density estimates provided by Tamungang et al. $(2013,2016)$ have been criticised for potentially being biased (Martin et al. 2014). Thus, a strong conclusion on the Grey Parrot population trend in the study area cannot be made.

Nevertheless, a comparison of own unpublished data from line transect surveys in 2002 and 2016 just north of the current study area (for details see Waltert et al. 2002) also suggest strong declines. In two c.16- $\mathrm{km}^{2}$ study areas (around the villages of Mgbegati and Bajo), encounter rates declined by $>85 \%$, from 3.55 flocks per $\mathrm{km}$ in $2002\left(n_{\text {records }}=455, L=128 \mathrm{~km}\right)$ to 0.50 flocks per $\mathrm{km}$ in 2016 ( $n_{\text {records }}=68, L=164 \mathrm{~km}$, own unpubl. data). Such a severe population decline within a short time period indicates that wildlife depletion in and around KNP, which has been documented for other species (Linder and Oates 2011), is likely to be affecting Grey Parrots. This is especially remarkable, since there has been considerable and continuous conservation funding for the Korup region (the Korup Project 1986-2002, Programme for the Sustainable Management of Natural Resources PSMNR-SWR since 2006, see also MINFOF 2017). Using similar data collection and analysis methods, Marsden et al. (2015) estimated much higher parrot population densities at other Cameroonian sites, such as Campo Ma'an $\left(D_{2013}=10.9\right.$ ind. $\left./ \mathrm{km}^{2}\right)$ or Lobeke $\left(D_{2013}=29.6\right.$ ind. $\left./ \mathrm{km}^{2}\right)$. Though this variability in parrot density estimates might have ecological as well as methodological reasons, Marsden et al. (2015) also suggested that good protected area management may play a role in this.

Our encounter rates and density estimates differed between the three landscapes studied. That KNP produced the lowest density estimate may be unexpected because primary lowland 
rainforest is supposed to represent the natural habitat of the Grey Parrot (Martin et al. 2014a, Birdlife International 2017a). Conclusions on habitat suitability and equilibrium densities are, however, difficult since high mobility of birds may require analyses at even larger spatial and temporal scales than those we present here (more than several hundred hectares in the three different landscapes). Indeed, Grey Parrots were often seen flying from the park during the morning towards the oil palm plantation and back during the evening, suggesting a daily routine. The few flocks we observed inside the park were mostly seen perching close to the Mana River, which is also next to the park border, always in the canopy of mature Lecomtedoxa klaineana trees. Therefore, the differences in density estimates between the park and the surrounding agroforestry landscape may be at least partially a result of the high mobility and long feeding periods in oil palms and farmland.

We observed parrots feeding on fruits of Elaeis guineensis and these may indeed be among those favoured by Grey Parrots (as also suggested by others, e.g. Naurois 1981, Tamungang et al. 2016), providing highly valuable energy. Naurois (1981) reported that Grey Parrots used holes formed in the top of rotten oil palm trunks for nesting on Formosa Island. However, this has not been reported from other sites and it remains open whether the homogeneous structure of an industrial oil palm plantation could provide such breeding opportunities. Given the ongoing expansion of oil palm plantations in the Afrotropical forest region (Linder and Palkovitz 2016), it seems reasonably to further investigate their ecological role for Grey Parrots aside from being permanent feeding habitats.

Interestingly, in the traditional smallholder agroforestry landscape, we estimated much higher densities than in either industrial oil palm or Korup National Park. Overall, the agroforestry landscape in the Korup region seems to be most diverse in regard to structure and resource availability: there, parrots may find a variety of nutritious crops (Amuno et al. 2007, Tamungang et al. 2016), and many high trees, either remnants of the original forest, regenerating pioneer trees or those planted decades ago. These may also provide safe lookouts and some of them also breeding cavities. As such, a mixed landscape composed of forest, farmland and fallows may provide high habitat quality, as has also been discussed for Grey Parrots in Uganda (Dranzoa 1995, Amuno et al. 2007).

Tamungang et al. (2016) reported that the abundance of parrots in the primary forest of KNP may be lower than in the AFM constantly across seasons. On the island of Príncipe, Valle et al. (2017) found higher parrot densities in landscapes dominated by agricultural estates and secondary forest patches only during post-breeding when food availability was high. However, since these human-dominated landscapes presumably did not provide sufficient breeding opportunities, parrot distribution evened out between pristine and secondary forest areas during pre-breeding. In contrast, we estimated a higher density in the AFM compared to KNP during pre-breeding, which may support the idea that the traditional smallholder farming practice in the Korup region may create an important breeding habitat. In line with that, Marsden et al. (2015) estimated similar levels of Grey Parrot densities $\left(D=4 . I\right.$ ind. $\left./ \mathrm{km}^{2}\right)$ in comparable agricultural areas with remnant forest patches near Yaoundé.

\section{Tree species used and other observations}

Though the tree canopy in the southern sector of KNP is dominated by Oubanguia alata (Lecythidaceae) and various Fabaceae species (Gartlan et al. 1986, Chuyong et al. 2004), we did not observe any parrots in those trees. Instead, we recorded parrots only at Lecomtedoxa klaineana (Sapotaceae), although without determining their activity within these trees. The absence of feeding observations in tree species that have been reported elsewhere, might be due to the limited number of parrot encounters in KNP or reflect methodological limitations of observing parrot behaviour in the high and dense canopy from the ground. On the other hand, it might also be a result of low seasonal availability of food in these trees compared with the adjacent landscapes outside the park. 
In contrast, inside the AFM, parrots were seen on a variety of different tree species as well as leafless dead trees. The most frequented tree was Terminalia superba. This species provides cavities and is known to be a major breeding tree for P. erithacus in the study area (Tamungang et al. 2013, 2016, Annorbah et al. 2016, this study). Annorbah et al. (2016) list Ceiba pentandra as possible nesting tree. While we recorded parrots at this tree species in the AFM, we did not find signs of breeding. However, local farmers also identified Ceiba pentandra (Oroko dialect: 'booma') and Terminalia superba ('white-afara') as breeding trees. One farmer in Fabe showed us two T. superba trees around his cacao farm, whose tree holes (at $8 \mathrm{~m}, 9.5 \mathrm{~m}$ and $19 \mathrm{~m}$ ) were supposedly used for parrot breeding.

According to observations from former years, the main parrot breeding season in the study area is July to September. Farmers claimed a link between the initiation of parrot breeding and the main ripening of fruits starting in June, especially of the bush plum Dacryodes edulis, a tree frequently visited by parrots. In contrast to other reports (see Perrin 2012), we neither observed nor received any reports on parrots feeding on maize in the AFM, even during the start of the harvest season in May, which might be attributed to high hunting pressure in the study area.

\section{Conclusion}

Although difficult to estimate declines accurately, our results may suggest that Grey Parrot populations in Cameroon's Korup area have decreased dramatically between 2008 and 2016. Given that forest cover remains high in the region it seems likely that these declines have been driven mainly by trapping for the trade, suggesting the transfer of the species to Appendix I of CITES (CITES 2016) potentially decreasing commercial export of this species was a prudent conservation action. We also found that daytime parrot density estimates differ between landscape types being highest in heterogeneous agroforestry mosaics. This suggests that Grey Parrots are at least to some extent able to adapt to substantial habitat alterations, if large trees are maintained as breeding and roosting sites. Our study highlights the urgent need for a stronger prioritization of Grey Parrots within conservation programmes and the development of multi-facetted conservation strategies containing: (i) effective eco-guard patrolling schemes in the Korup region (Astaras et al. 2017), (ii) a consequent inhibition of illegal pet trade routes and markets in the entire region of SW Cameroon/SE Nigeria, and (iii) the promotion of traditional agroforestry practices in preference to monocultural agriculture (Kupsch et al. 2019). Such steps along with the implementation of CITES will help prevent further over-exploitation and future declines of wild populations in the region.

\section{Supplementary Material}

To view supplementary material for this article, please visit https://oi.org/10.1017/ S0959270919000194

\section{Acknowledgements}

We would like to thank Stuart Marsden for encouraging us to carry out this study. Furthermore, we are grateful to those assisting us during fieldwork, especially Njie Francis, Mambo Peter, Linus Arong, Motia Innocent, Ngoe Monclaire and Chokeni Wilson. Special thanks go to the Korup Rainforest Conservation Society (KRCS) in Mundemba for logistic support. We are also immensely grateful to Rowan Martin for providing detailed advice during the preparation of this manuscript, to James Gilardi and one anonymous reviewer for helpful comments on the manuscript, as well as to Simon Tamungang for explanations of his survey methodology. Financial support for fieldwork was provided by the Gesellschaft für Tropenornithologie e.V. GTO (SD) and the Heinrich-Böll Foundation (DK). 


\section{References}

Amuno, J. B., Massa, R. and Dranzoa, C. (2007) Abundance, movements and habitat use by African Grey Parrots (Psittacus erithacus) in Budongo and Mabira forest reserves, Uganda. Ostrich 78: 225-231.

Annorbah, N. N. D., Collar, N. J. and Marsden, S. J. (2016) Trade and habitat change virtually eliminate the Grey Parrot Psittacus erithacus from Ghana. Ibis 158: 82-91.

Astaras, C., Linder, J. M., Wrege, P., Orume, R. D. and Macdonald, D. W. (2017) Passive acoustic monitoring as a law enforcement tool for afro-tropical rainforests. Front. Ecol. Environ. 15: 233-234.

BirdLife International (2017a) Species factsheet: Psittacus erithacus. http://www. birdlife.org. on 04 September 2017.

BirdLife International (2017b) Species factsheet: Psittacus timneh. http://www.birdlife.org. Assessed on 04 September 2017.

Bobo, K. S., Waltert, M., Fichtler, M. and Mühlenberg, M. (2005) New bird records for the Korup project area, Southwest Cameroon. Malimbus 27: 13-18.

Buckland, S. T., Anderson, D. R., Burnham, K. P., Laake, J. L., Borchers, D. L. and Thomas, L. (2001) Introduction to distance sampling: estimating abundance of biological populations. Oxford, UK: Oxford University Press.

Chupezi, T. J., Ndoye, O. and Mpele, T. O. (2006) Commodity-Chain Analysis for the capture and trade in the African grey parrots (Psittacus erithacus erithacus) in Cameroon. Yaoundé, Cameoron: Center for International Forestry Research (CIFOR).

Chuyong, G. B., Condit, R., Kenfack, D., Losos, E. C., Moses, S. N., Songwe, N. C. and Thomas, D. W. (2004) Korup forest dynamics plot, Cameroon. Pp. 506-516 in E. C. Losos, and E. G. Leigh Jr, eds. Tropical forest diversity and dynamism. Chicago, Illinois: University of Chicago Press.

CITES (2016) Section 6.2. Consideration Proposals for Amendment of Appendices I and II. Transfer from Appendix II to Appendix I of Psittacus erithacus in accordance with Resolution Conf. 9.24. https://cites.org/. Accessed on 4 September 2017.

Clemmons, J. R. (2003) Status survey of the African Grey Parrot (Psittacus erithacus timneh) and development of a management program in Guinea and Guinea-Bissau. Geneva, Switzerland: Unpublished report to the CITES Secretariat.

Collar, N. J. (2013) Timneh parrot and Grey Parrot represent two species. http:// stuartmarsden.blogspot.co.uk/2013/12/ timneh-parrot-and-grey-parrot-represent. html. Accessed on 4 September 2017.

Dranzoa, C. (1995) Bird populations of primary and logged forests in Kibale Forest National Park, Uganda. Ph.D. dissertation, Makerere University, Uganda.

Eniang, E. E., Akpan, C. E. and Eniang, M. E. (2008) A survey of African Grey parrots (Psittacus erithacus) trade and trafficking in Ekonganaku area of Ikpan forest block, Nigeria. Ethiopian J. Environ. Stud. Manage. 1: 68-73.

Fa, J. E., Seymour, S., Dupain, J., Amin, R., Albrechtsen, L. and Macdonald, D. (2006) Getting to grips with the magnitude of exploitation: bushmeat in the Cross-Sanaga rivers region, Nigeria and Cameroon. Biol. Conserv. 129: 497-510.

Fotso, R. (1998a) Survey status of the distribution and utilization of the Grey Parrot (Psittacus erithacus) in Cameroon. Geneva, Switzerland: CITES.

Fotso, R. (1998b) Etude sur l'état, la répartition géographique et l'utilisation du perroquet gris (Psittacus erithacus) dans la République démocratique du Congo. Geneva, Switzerland: CITES.

Gartlan, J. S., Newbery, D. M., Thomas, D. W. and Waterman, P. G. (1986) The influence of topography and soil phosphorus on the vegetation of Korup Forest Reserve, Cameroun. Vegetatio 65: 131-148.

Gnam, R. S. (1991) Nesting behaviour of the Bahama Parrot (Amazona leucocephala bahamensis) on Abaco Island, Bahamas. Proc. Internatn. Ornithol. Congress 20: 673-680.

Green, A. A., Hall, P. and Leventis, A. P. (2007) Avifauna of Omo Forest Reserve, SW Nigeria. Malimbus 29: 16-30.

Kupsch, D., Vendras, E., Ocampo-Ariza, C., Batáry, P., Motombi, F. N., Bobo, K. S. and Waltert, M. (2019) High critical forest habitat thresholds of native bird communities 
in Afrotropical agroforestry landscapes. Biol. Conserv. 230: 20-28.

Lee, A. T. and Marsden, S. J. (2012) The influence of habitat, season, and detectability on abundance estimates across an Amazonian parrot assemblage. Biotropica 44: 537-544.

Legault, A., Theuerkauf, J., Baby, E., Moutin, L., Rouys, S., Saoumoé, M., Verfaille, L., Barré, N., Chartendrault, V. and Gula, R. (2013) Standardising distance sampling surveys of parrots in New Caledonia. J. Ornithol. 154: 19-33.

Linder, J. M. and Oates, J. F. (2011) Differential impact of bushmeat hunting on monkey species and implications for primate conservation in Korup National Park, Cameroon. Biol. Conserv. 144: 738-745.

Linder, J. M. and Palkovitz, R. E. (2016) The threat of industrial oil palm expansion to primates and their habitats. Pp. 21-45 in M. T. Waller, ed. Ethnoprimatology: Primate Conservation in the 21st Century. Berlin, Germany: Springer.

Marsden, S. J., Pilgrim, J. D. and Wilkinson, R. (2001) Status, abundance and habitat use of blue-eyed cockatoo Cacatua ophthalmica on New Britain, Papua New Guinea. Bird Conserv. Internatn. 11: 151-160.

Marsden, S. J., Loqueh, E., Takuo, J. M., Hart, J. A., Abani, R., Ahon, D. B., Annorbah, N. N. D., Johnson, R. and Valle, S. (2015) Using encounter rates as surrogates for density estimates makes monitoring of heavily-traded grey parrots achievable across Africa. Oryx 50: 617-625.

Martin, R. O., Perrin, M. R., Boyes, R. S., Abebe, Y. D., Annorbah, N. N. D. et al. (2014a) Research and conservation of the larger parrots of Africa and Madagascar: a review of knowledge gaps and opportunities. Ostrich 85: 205-233.

Martin, R. O., Gilardi, J., Johnson, R., Ndang'ang'a, P. K., Fotso, R., Drori, O. and Perrin, M. (2014b) Grey parrot Psittacus harvesting for conservation must have a robust scientific basis: Commentary on Tamungang et al. (2013). Internatn. J. Biodivers. Conserv. 6: 750-753.

Martin, R. O. (2018a) The wild bird trade and African parrots: past, present and future challenges. Ostrich 89: 139-143.
Martin, R. O. (2018b) Grey areas: temporal and geographical dynamics of international trade of Grey and Timneh Parrots (Psittacus erithacus and P. timneh) under CITES. Emu 118: 113-125.

McGowan, P. (2001) Status, management and conservation of the African Grey Parrot Psittacus erithacus in Nigeria. Geneva, Switzerland: Unpublished report to CITES.

MINFOF (2017) The Management Plan for Korup National Park and its peripheral zone 2017-2021. Buea, Cameroon: Regional Delegation of the Ministry of Forestry and Wildlife.

Mittermeier, R. A., Robles-Gil, P., Hoffmann, M., Pilgrim, J. D., Brooks, T. B., Mittermeier, C. G., Lamoreux, J. L. and Fonseca, G. A. B. (2004) Hotspots revisited: Earth's biologically richest and most endangered ecoregions. Mexico City, Mexico: CEMEX.

Naurois, R. de (1981) La distribution géographique du perroquet gris Psittacus erythacus timneh. Malimbus 3: 59-61.

Perrin, M. (2012) Parrots of Africa, Madagascar and the Mascarene Islands: biology, ecology and conservation. Johannesburg, South Africa: Wits University Press.

Pinho, J. B. and Nogueira, F. M. B. (2003) Hyacinth Macaw (Anodorhynchus hyacinthinus) reproduction in the Northern Pantanal, Mato Grosso, Brazil. Ornitol. Neotrop. 14: 29-38.

Reuleaux, A., Richards, H., Payet, T., Villard, P., Waltert, M. and Bunbury, N. (2014a) Breeding ecology of the Seychelles black parrot Coracopsis barklyi. Ostrich 85: $255-265$.

Reuleaux, A., Richards, H., Payet, T., Villard, P., Waltert, M. and Bunbury, N. (2014b) Insights into the feeding ecology of the Seychelles Black Parrot Coracopsis barklyi using two monitoring approaches. Ostrich 85: 245-253.

Sedgwick, J. A. (1997) Sequential cavity use in a cottonwood bottomland. Condor 99: 880-887.

Tamungang, S. A. and Cheke, R. A. (2012) Population status and management plan of the African Grey Parrot (SC62 Inf. 14). Report prepared by the Ministry of Forestry and Wildlife, Cameroon. Geneva, Switzerland: CITES Secretariat. 
Tamungang, S. A., Cheke, R. A., Kougoum, G. P. and Ntiri, E. S. (2013) Linking population size to conservation needs of the Grey Parrot in Cameroon. Internatn. J. Biodivers. Conserv. 5: 478-485.

Tamungang, S. A., Onabid, M. A., Awa, T. and Balinga, V. S. (2016) Habitat preferences of the Grey Parrot in heterogeneous vegetation landscapes and their conservation implications. Internatn. J. Biodiversity 2016: Article ID: 7287563.

Thomas, D. W. (1996) Botanical survey of the Rumpi Hills and Nta Ali. Report to the GTZ, Germany, and to the Korup Project, Mundemba, Cameroon.

Thomas, L., Buckland, S. T., Rexstad, E. A., Laake, J. L., Strindberg, S., Hedley, S. L.,
Bishop, J. R. B., Marques, T.A. and Burnham, K. P. (2010) Distance software: design and analysis of distance sampling surveys for estimating population size. J. Appl. Ecol. 47: 5-14

Valle, S., Collar, N. J., Harris, W. E. and Marsden, S. J. (2017) Spatial and seasonal variation in abundance within an insular grey parrot population. Afr. J. Ecol. 55: 433-442.

Walsh, P. D. and White, L. J. (1999) What it will take to monitor forest elephant populations. Conserv. Biol. 13: 1194-1202.

Waltert, M., Lien, , Faber, K. and Mühlenberg, M. (2002) Further declines of threatened primates in the Korup Project Area, southwest Cameroon. Oryx 36: 257-265.

\section{SASCHA DUEKER, DENIS KUPSCH*, MATTHIAS WALTERT}

Conservation Biology/Workgroup on Endangered Species, University of Goettingen, Buergerstrasse 50, 37073 Goettingen, Germany.

\section{SERGE KADIRI BOBO}

Department of Forestry, University of Dschang, P.O. Box 222, Dschang, Cameroon.

\section{ECKHARD W. HEYMANN}

Behavioral Ecology and Sociobiology Unit, German Primate Center - Leibniz Institute for Primate Research, Kellnerweg 6, 37077 Goettingen, Germany.

*Author for correspondence; e-mail:dkupsch@gwdg.de

Received 21 December 2018; revision accepted 24 April 2019; Published online 21 June 2019 